\title{
Depletion of OX-8 Lymphocytes from the Blood and Airways Using Monoclonal Antibodies Enhances the Late Airway Response in Rats
}

R. Olivenstein, P. M. Renzi, J. P. Yang, P. Rossi, S. Laberge, S. Waserman, and J. G. Martin

Meakins-Christie Laboratories, Royal Victoria Hospital, McGill University, and Andre Viallet Research Institute, Pulmonary Unit,

St-Luc Hospital, University of Montreal, Montreal, Quebec, Canada H2X 2P2

\section{Abstract}

Recent evidence supports a role for $T$ lymphocytes in allergic airway responses. We hypothesized that reducing blood $T$ suppressor cells (Ts) might increase the late airway response (LR). Sprague-Dawley (SD) rats were sensitized with ovalbumin (OA). On days 8, 10, and 12, postsensitization test $\operatorname{SD}(n=14)$ received monoclonal antibody intravenously $(\mathrm{OX}-8 ; 1 \mathrm{mg}) \mathrm{spe}-$ cific to rat Ts. Controls received saline $(n=7)$ or mouse ascites IgG $(n=7)$. On day 14 , animals were challenged with OA aerosol (5\% wt/vol) for $5 \mathrm{~min}$, lung resistance was recorded for $8 \mathrm{~h}(n=18)$ and bronchoalveolar lavage was performed. The LR was determined from the area under the lung resistance vs time curve from 75 to $480 \mathrm{~min}$ after challenge. In the remaining 10 rats, airway lymphocyte subsets were measured $8 \mathrm{~h}$ after OA aerosol challenge in minced and digested lungs. A decrease in percentage of blood and airway $\mathrm{Ts}$, respectively, in test animals was observed vs controls (blood: $6.27 \pm 0.84$ vs 32.95 $\pm 1.94, P<0.001$ ); (airway: $5.05 \pm 0.66$ vs $24.5 \pm 3.05, P$ $<0.02)$. Blood and airway helper $T$ lymphocytes did not differ between test and control animals. The $L R$ was significantly increased in test $(22.89 \pm 3.92)$ vs controls $(4.22 \pm 2.18, P$ $<0.001$ ). Bronchoalveolar lavage macrophages, neutrophils and lymphocytes, and serum OA-specific IgE were also significantly elevated $(P<0.05)$ in test animals. We conclude that Ts play an important role in attenuating the $L R$ in SD rats. ( $J$. Clin. Invest. 1993. 92:1477-1482.) Key words: allergic bronchoconstriction • late responses • OX-8 monoclonal antibody • suppressor lymphocytes • airway inflammation

\section{Introduction}

Recent evidence supports a role for the $\mathrm{T}$ lymphocyte in allergic airway responses (1-4). Although the evidence is circumstantial, there is ample reason to suggest that the $T$ lymphocyte may be central to the airway inflammation that comes after allergen challenge. $T$ lymphocyte-derived lymphokines play an important role in the regulation of IgE production and in mast cell and eosinophil differentiation and function (5-10). In particular, T lymphocyte suppressor cell dysfunction may have a pathogenetic role in atopic disease states. A relative def-

Address correspondence and reprint requests to Dr. James G. Martin, Meakins-Christie Laboratories, McGill University, 3626 St. Urbain St., Montreal, Quebec, Canada H2X 2P2.

Received for publication 28 August 1992 and in revised form 23 March 1993.

\section{J. Clin. Invest.}

(c) The American Society for Clinical Investigation, Inc.

0021-9738/93/09/1477/06 \$2.00

Volume 92, September 1993, 1477-1482 ciency of suppressor $\mathrm{T}$ lymphocytes has been reported in patients with allergic rhinitis $(11,12)$, atopic dermatitis (13), and both allergic (14) and nonallergic asthma $(15,16)$. A decrease in $\mathrm{T}$ lymphocyte suppressor cell numbers and in mitogen induced suppressor cell activity has been described in asthma (17-22). A decrease in peripheral blood suppressor cells has been shown in chronic asthmatics who were refractory to corticosteroid therapy (23).

We hypothesized that suppressor cells are involved in the late airway response that comes after antigen challenge, and that selective depletion of $T$ suppressor cells using monoclonal antibodies would increase the late airway response to antigen challenge. To test this hypothesis, we used the mouse anti-rat monoclonal antibody OX-8, which is specific for suppressor/ cytotoxic $T$ lymphocytes and natural killer cells $(24,25)$. We studied the effect of previous administration of this antibody on antigen induced immediate and late bronchoconstriction in sensitized Sprague-Dawley rats. These rats developed homocytotropic IgE after sensitization, but late airway responses were uncommon (26). Therefore, we chose the Sprague-Dawley rat to test the effects of depletion of lymphocytes containing OX-8 surface receptor $(\mathrm{OX}-8+)$ cells on the airway physiological and inflammatory changes that come after antigen challenge.

\section{Methods}

Animals and sensitization. Experiments were performed on male Sprague-Dawley rats obtained from a commercial source (Harlan Sprague-Dawley, Indianapolis, IN). Rats were maintained in conventional animal facilities at McGill University (Montreal, Quebec).

At the start of the experiment, rats ranged in age from 8 to $10 \mathrm{wk}$ and weighed from 270 to $430 \mathrm{~g}$. 28 animals were actively sensitized with a subcutaneous injection of $1 \mathrm{mg}(0.8 \mathrm{ml})$ of chicken egg ovalbumin (OA) ${ }^{1}$ (grade V; Sigma Immunochemicals, St. Louis, MO) precipitated in $3.48 \mathrm{mg}$ of aluminum hydroxide gel in normal saline $(0.2 \mathrm{ml})$. On the same occasion, $0.5 \mathrm{ml}$ of Bordetella pertussis vaccine containing $1 \times 10^{10}$ heat-killed bacilli was injected intraperitoneally as an adjuvant.

Study protocol. On days 8, 10, and 12 after sensitization, animals received an intravenous injection of either $1 \mathrm{mg}$ of a mouse monoclonal antibody specific to rat suppressor T lymphocytes $(O X-8 ; n=14)$ or $1 \mathrm{mg}$ of ascites from pristaned BALB/c mice injected intraperitoneally with SP2/0 myeloma cells (protein concentration $82.7 \pm 1.1 \mathrm{mg} / \mathrm{ml})(n$ $=7$ ) or saline ( $1 \mathrm{ml} ; n=7)$. On day 14 , blood was obtained for OA-specific IgE and lymphocyte subset measurements. Antigen challenge was performed and pulmonary resistance $\left(\mathbf{R}_{\mathbf{L}}\right)$ measurements were obtained in OX-8-treated $(n=8)$, ascites-treated $(n=3)$, and salinetreated $(n=7)$ rats for $8 \mathrm{~h}$, and then bronchoalveolar lavage (BAL) was

1. Abbreviations used in this paper: $\mathrm{BAL}$, bronchoalveolar lavage; $\mathrm{OA}$, ovalbumin; OX-8 mAb, mouse anti-rat OX-8 monoclonal antibody; $\mathrm{OX}-8^{+}$, lymphocytes containing $\mathrm{OX}-8$ surface receptor; $\mathrm{R}_{\mathrm{L}}$, pulmonary resistance; $\mathrm{Ts}$, $\mathrm{T}$ suppressor cells. 
performed. In the remaining 10 rats (six administered $O X-8$ and four controls), $8 \mathrm{~h}$ after $\mathrm{OA}$ aerosol challenge, the lungs were minced and digested for the measurement of inflammatory cell infiltration (27). To evaluate the possibility that $\mathrm{OX}-8 \mathrm{mAb}$ pretreatment, per se, might induce lung inflammation, another group of rats underwent sham sensitization with saline and then received $1 \mathrm{mg} \mathrm{OX-8} \mathrm{mAb} \mathrm{i.v.} \mathrm{on} \mathrm{days} 8$, 10 , and 12 after sham sensitization. On day 14 , anesthetized, intubated rats underwent BAL and were compared to saline-injected controls $(n=5)$.

Measurement of pulmonary mechanics. Measurement of airway response was performed as previously described $(28)$ in animals that were anesthetized with urethane $(1.1 \mathrm{~g} / \mathrm{kg})$ and orotracheally intubated. $R_{L}$ was determined by fitting the equation of motion of the lung to the data by multiple linear regression analysis using a commercial software package (RHT Infodat Inc., Montreal, Quebec).

Measurement of airway responses to ovalbumin. On day 14 after sensitization, rats were anesthetized, intubated, placed on a heating pad, and rectal temperature was continuously monitored with an electronic thermometer (Telethermometer; Yellow Springs Instrument Co., Yellow Springs, $\mathrm{OH}$ ). Animals were kept in the lateral decubitus position and alternated between left and right sides hourly. $\mathbf{R}_{\mathbf{L}}$ was measured at baseline, after a 5-min saline aerosol administration, immediately after the administration of aerosols of ovalbumin, 5,10 , and $15 \mathrm{~min}$ after the ovalbumin and subsequently at 15 -min intervals for a total period of $8 \mathrm{~h}$. Aerosols of ovalbumin $(5 \% \mathrm{wt} / \mathrm{vol})$ were administered for 5 min using a Hudson nebulizer driven by a compressed air source of 10 liters $/ \mathrm{min}$ resulting in a nebulizer output of $0.16 \mathrm{ml} / \mathrm{min}$.

Lung mincing and digestion. Lung mincing and digestion was performed as previously described (27). Briefly, under general anesthesia, the chest wall was opened and the animal was exsanguinated by puncture of the left ventricle. The pulmonary vasculature was flushed with a balanced salt solution $(10 \mathrm{ml})$ injected into the right ventricle until the effluent from the lungs was white. The lungs were separated into the large airways (trachea and large bronchi until the fifth generation, approximately), and small airways and parenchyma, washed in balanced salt solution, cut into 1-mm sections, and incubated separately for tissue digestion. Tissue digestion was performed by three 20-min incubations in $20 \mathrm{ml}$ of enriched RPMI 1640 medium (RPMI 1640 supplemented with $100 \mathrm{U} / \mathrm{ml}$ of penicillin, $100 \mu \mathrm{g} / \mathrm{ml}$ of streptomycin, $10 \%$ heat inactivated fetal calf serum, $2 \mathrm{mmol} / \mathrm{liter} \mathrm{L}$-glutamine, and 0.1 $\mathrm{mmol} /$ liter nonessential amino acids) containing $20 \mathrm{U} / \mathrm{ml}$ collagenase. After each incubation, cells were separated from tissue by filtration through a sieve (model 60; Sigma Immunochemicals) and washed three times in RPMI. At the end of all three incubations, the cells were pooled and counted on a hemocytometer. Slides were prepared by centrifuging 500,000 cells in enriched RPMI 1640 for $5 \mathrm{~min}$ at $700 \mathrm{rpm}$ in a cytocentrifuge (Cytospin-3; Shandon, Cheshire, United Kingdom). Cellular differential was assessed on a Wright Giemsa stain; 200 cells were counted under oil immersion microscopy.

Isolation and staining of blood lymphocyte subsets. Mononuclear cells were isolated from fresh heparinized peripheral blood by standard Ficoll-Hypaque methods and prepared for flow cytometry. Indirect staining was performed by a 30 -min incubation with the monoclonal antibodies W3/25 and OX-8, which recognize the helper and suppressor subsets respectively. After washing, a second incubation was performed for $\mathbf{3 0}$ min with a FITC-conjugated rabbit anti-mouse IgG antibody. Stained cells were fixed in $1 \%$ paraformaldehyde $/ 0.85 \%$ saline and stored at $4^{\circ} \mathrm{C}$ in the dark until analysis. Flow cytometry was performed with an argon laser, 488-nm FACScan ${ }^{\star}$ analyzer (Becton Dickinson FACS ${ }^{\oplus}$ Division, Sunnyvale, CA) focusing on the lymphocyte cluster. Viability was determined by adding propidium iodide (1 $\mu \mathrm{g} / \mathrm{ml}$ ) to unfixed specimens and averaged $96 \pm 3 \%$. Controls consisted of cells stained with mouse ascites antibodies and averaged $1.9 \pm 0.4 \%$.

Lung lavage. BAL was performed in OX-8- $(n=6)$ treated animals, and in ascites IgG- $(n=3)$ and saline- $(n=4)$ treated controls. The lungs were lavaged through the endotracheal tube by instillation of $5 \mathrm{ml}$ of saline at room temperature followed by gentle aspiration and repeated five times. The volume retrieved averaged $83 \%$ of the $25 \mathrm{ml}$ that were instilled. The total cell count was determined on a fresh specimen of fluid using a haemocytometer. Slides were prepared for differential cell count by centrifuging for $1 \mathrm{~min}$ at $2,000 \mathrm{rpm}$ in a cytocentrifuge (Cytospin-2; Shandon). Cellular differential was assessed on a Wright Giemsa stain; 200 cells were counted under oil immersion microscopy.

$I g E$ determination. Specific IgE levels to OA were determined by ELISA as previously described (29). Briefly, assays were performed on 96-well microtiter plates (Immulon II; Fisher). Plates were coated overnight with mouse monoclonal antibody to rat IgE (Zymed Labs, Inc., San Francisco, CA) diluted $1 / 800$ in carbonate/bicarbonate buffer. Plates were blocked with PBS- $0.5 \%$ casein. A 1:10 dilution of serum in PBS- $0.5 \%$ casein was prepared prior to addition of $100 \mu$ lo the plates. Biotin-labeled OA $(0.02 \mathrm{mg} / \mathrm{ml})$ was added to the wells. The above steps were done at $2-\mathrm{h}$ intervals at $37^{\circ} \mathrm{C}$. Between steps the wells were washed three times with PBS- $0.5 \%$ casein. Alkaline phosphatase conjugated streptavidin in PBS- $0.5 \%$ casein (1:500 dilution) was added for 30 min. Plates were developed at room temperature for $15 \mathrm{~min}$ after addition of the appropriate substrate buffer, and were read with an ELISA plate reader (SLT Labinstruments, Fisher Scientific Co., Pittsburgh, PA) at $405 \mathrm{~nm}$.

$O X-8 m A b$ purification. OX-8 antibodies were obtained from an OX-8 hybridoma cell line (American Type Culture Collection, Rockville, $M D$ ), which produces monoclonal antibody specific to rat $T$ suppressor/cytotoxic lymphocytes. Crystylate OX-8 cell line was thawed and cultured in complete RPMI 1640 medium until dense layers were obtained. The culture was divided every 2-3 d, and then the culture medium was pooled and centrifuged at $4,000 \mathrm{rpm}$ for $15 \mathrm{~min}$ at $4{ }^{\circ} \mathrm{C}$ to collect the supernatant. The supernatant protein was precipitated with saturated ammonium sulfate and dialyzed against PBS. IgG was purified on a protein $A / G$ agarose affinity column, and the $O X-8$ fraction was again dialyzed against PBS before finally being concentrated with PEG. The protein content was $4.63 \mathrm{mg} / \mathrm{ml}$. $\mathrm{mAb}$ was passed through a $0.2-\mu \mathrm{m}$ millipore filter and stored at $-70^{\circ} \mathrm{C}$ until use.

Chemicals. Ovalbumin, Wright Giemsa stain and propidium iodide and collagenase were purchased from Sigma Immunochemicals; Ficoll-Hypaque was obtained from Pharmacia (Montreal, Quebec, Canada); Bordetella pertussis vaccine was purchased from Institut Armand Frappier (Montreal, Quebec, Canada); W3/25 and OX-8 mAb for staining were obtained as a gift from Dimension Labs (Mississauga, Ontario, Canada); FITC-conjugated rabbit anti-mouse $\mathrm{mAb}$ was obtained from Kappel, Organon Tecnica (Scarborough, Ontario, Canada); RPMI 1640 medium, penicillin, streptomycin, fetal calf serum, 1-glutamine, and nonessential amino acids were purchased from Gibco Laboratories (Grand Island, NY); BALB/c mouse control ascites fluid was purchased from Cedarlane Laboratories (Hornby, Ontario, Canada).

Statistical analysis. We defined a significant early airway response as an increase in $R_{L}$ to $\geq 150 \%$ of the baseline value within $1 \mathrm{~h}$ of $\mathrm{OA}$ challenge. In the Sprague-Dawley rats, the magnitude of the late airway response was determined from the area under the curve of $R_{L}$ $\left(\mathrm{cmH}_{2} \mathrm{O} \cdot \mathrm{ml}^{-1} \cdot \mathrm{s}\right)$ above the baseline value $+2 \mathrm{SD}$ vs time (minutes) of all measurements from 75 to $480 \mathrm{~min}$ after OA challenge. We also compared the $R_{L}$ from 75 min to $8 \mathrm{~h}$ between control and OX-8treated animals by ANOVA. Saline and IgG ascites treated controls were not different from each other and were pooled for comparison with OX-8-treated animals. The differences between group means were analyzed by unpaired $t$ tests, and statistical significance was assumed for $P<0.05$. Results are presented as mean \pm SEM.

\section{Results}

Early and late airway response to $O A$ aerosol. The baseline $R_{\mathrm{L}}$ for OX-8 treated animals was $0.229 \pm 0.03 \mathrm{~cm} \mathrm{H}_{2} \mathrm{O} \cdot \mathrm{ml}^{-1} \cdot \mathrm{s}$, which was not significantly different from controls, $0.213 \pm 0.02 \mathrm{~cm} \mathrm{H}_{2} \mathrm{O} \cdot \mathrm{ml}^{-1} \cdot \mathrm{s}$. Fig. 1 shows the mean lung resis- 


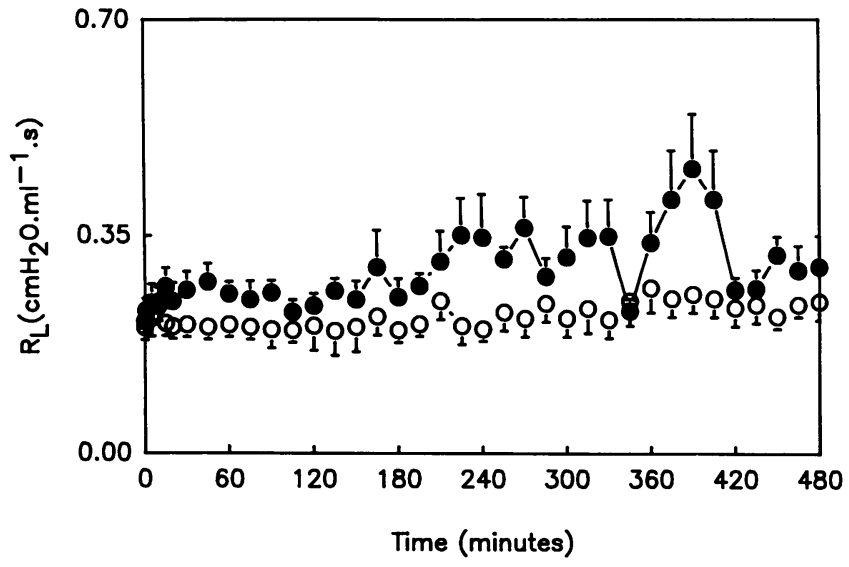

Figure 1. Effect of treatment with OX-8 (filled circle, $n=8$ ) on lung resistance after OA challenge in sensitized Sprague-Dawley rats vs controls (open circles, $n=10$ ). A significant between-group effect was demonstrated comparing $R_{L}$ during the late airway response (75-480 min after $O A$ challenge) (ANOVA, $P<0.0001$ ).

tance at each time point after saline or OA challenge. In OX-8treated animals, $R_{L}$ was significantly elevated during the late airway response (ANOVA, $P<0.0001$ ). An early airway response to OA challenge was observed in two out of eight OX-8treated animals, compared to 2 out of 10 controls. Overall, the mean maximum percent of baseline $R_{L}$ during the 60 min after OA challenge was not significantly different from controls, but the late airway response as measured by the area under the $R_{L}$ vs time curve was significantly elevated in OX-8-treated animals compared to controls, $P<0.001$ (Fig. 2).

Blood lymphocyte subsets. The percent of blood lymphocyte helper and suppressor cells observed before OA challenge is shown in Fig. 3. Blood helper lymphocytes $(n=6)$ did not differ significantly in the OX-8-treated animals (58.03 \pm 3.44$)$ compared to controls $(56.57 \pm 2.61 ; n=10)$, but blood suppressor lymphocytes $(n=8)$ were significantly reduced $(6.27 \pm 0.84)$ vs controls $(32.95 \pm 2.94 ; P<0.0001)$. There was no significant correlation between the percent blood suppressor cells and the late airway response within the group of OX-8-depleted animals.

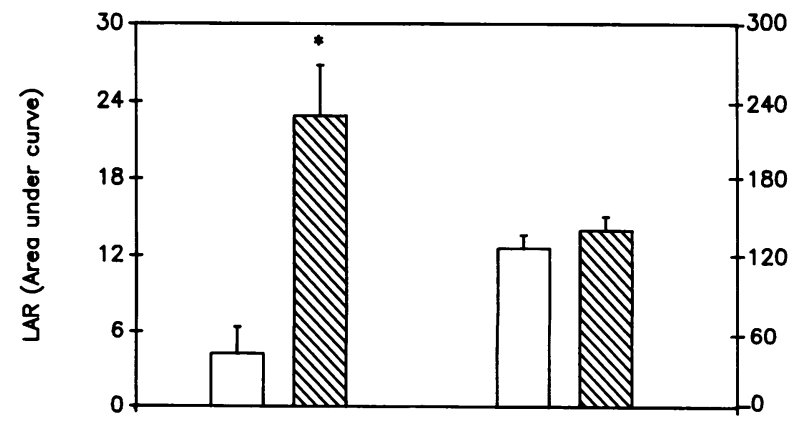

Figure 2. Effect of treatment with OX-8 (hatched bars, $n=8$ ) on the early and late airway response to antigen challenge vs controls (open bars, $n=10$ ). The early response is expressed as the percent of the baseline pulmonary resistance $\left(R_{L}\right)$. The late response is calculated as the area under the curve of the $\mathrm{R}_{\mathrm{L}}\left(\mathrm{cmH}_{2} \mathrm{O} \cdot \mathrm{ml}^{-1} \cdot \mathrm{s}\right)$ and time (minutes). ${ }^{*} P<0.001$

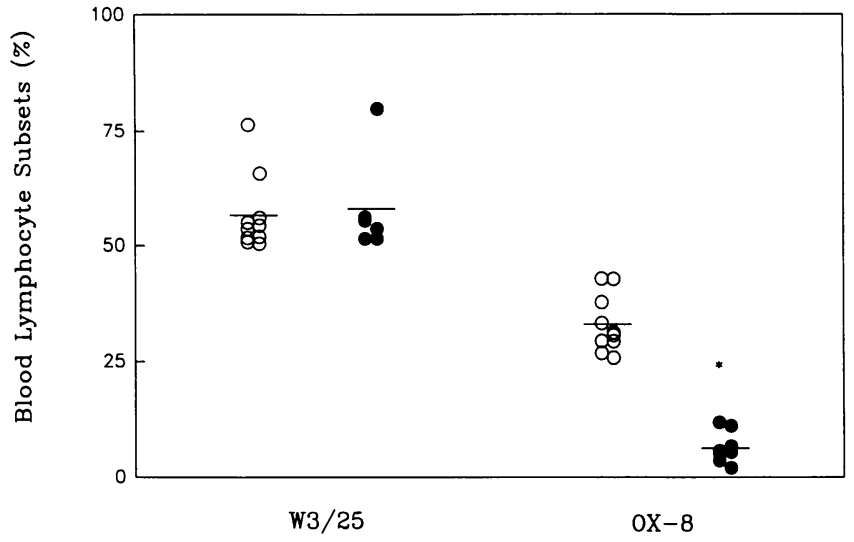

Figure 3. Effect of treatment with OX-8 (filled circles) on the percentage of blood lymphocyte $\mathrm{CD}^{+}(\mathrm{W} 3 / 25, n=6)$ and $\mathrm{CD}^{+}(\mathrm{OX}-8$, $n=8$ ) cells vs controls (open circles, $n=10$ ). ${ }^{*} P<0.001$

Airway lymphocyte subsets. The percent of airway lymphocyte helper and suppressor cells observed $8 \mathrm{~h}$ after OA aerosol challenge is shown in Fig. 4. Percent helper lymphocytes were slightly elevated in the OX-8-treated group (46.18 $\pm 7.08 ; n$ $=7$ ) compared to controls $(28.84 \pm 4.78 ; n=4)$, but the difference was not significant. Percent airway lymphocyte suppressors were significantly decreased $(5.05 \pm 0.66)$ vs controls (24.5 $\pm 3.05 ; P<0.02)$. Also, the ratio of helper to suppressor lymphocytes in the airway was significantly greater in the OX8 -treated group $(10.42 \pm 2.69)$ vs controls $(1.13 \pm 0.10 ; P$ $<0.005)$.

Bronchoalveolar lavage. The results of BAL performed $8 \mathrm{~h}$ after aerosol challenge in six OX-8-treated animals and seven controls are shown in Fig. 5. The numbers of total leukocytes, macrophages, polymorphonuclear neutrophils, and lymphocytes were significantly elevated in BAL of animals treated with OX-8 compared to controls. The numbers of eosinophils found in BAL were small in both OX-8-treated animals $\left(3.67 \pm 2.15 \times 10^{3}\right)$ and in controls $\left(2.00 \pm 1.29 \times 10^{3}\right)$, and were not significantly different. In animals that were not allergen sensitized or challenged, there was no significant difference in the total leukocytes and differential counts in the BAL after

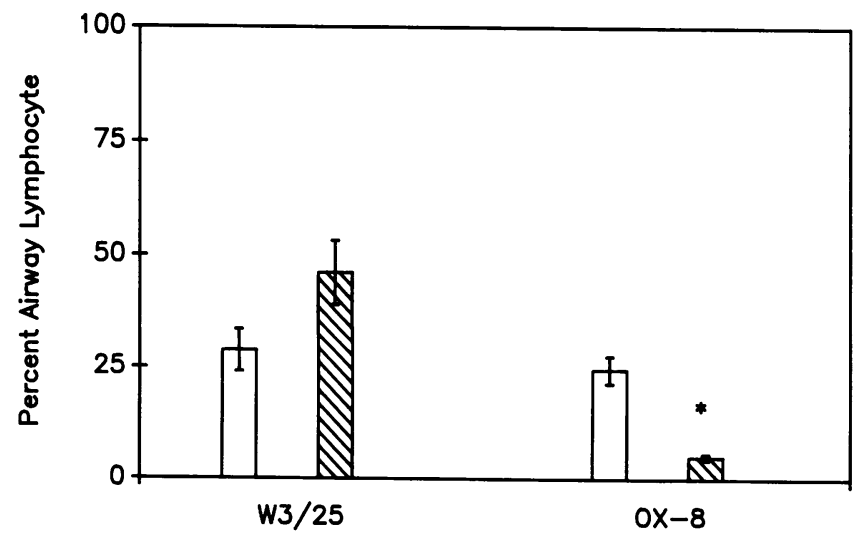

Figure 4. Effect of treatment with OX-8 (hatched bars, $n=7$ ) on the percentage of airway lymphocyte CD4+ (W3/25) and $\mathrm{CD}^{+}(\mathrm{OX}-8)$ cells vs controls (open bars, $n=4$ ). ${ }^{*} P<0.02$ 


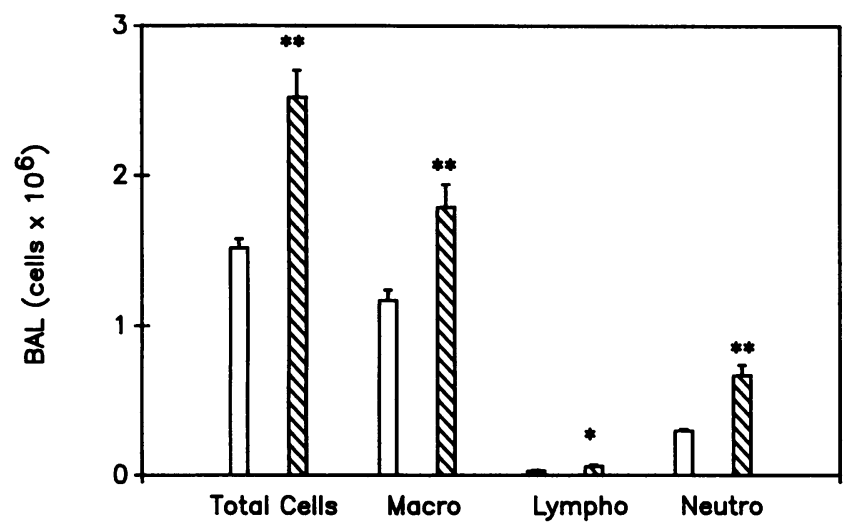

Figure 5. Effect of treatment with OX-8 (hatched bars, $n=6$ ) on cellular return in BAL vs controls (open bars, $n=7$ ). Eosinophils were too few in number to represent graphically.

administration of OX-8 mAb compared to saline treated controls (Table I), indicating that $\mathrm{OX}-8$ treatment, per se, did not induce lung inflammation.

$O A$-specific IgE. Ovalbumin specific IgE was detected in six of eight OX-8-treated animals $(0.33 \pm 0.09$ absorbance units) but in only 1 of 10 controls $(0.01 \pm 0.01 ; P<0.02)$.

\section{Discussion}

The current study provides evidence for an important role for $\mathrm{CD}^{+} \mathrm{T}$-lymphocytes in the regulation of the late airway response in the Sprague-Dawley rat. Previous depletion of circulating and airway $\mathrm{CD}^{+} \mathrm{T}$ lymphocytes with a monoclonal antibody significantly increased the magnitude of the late airway response to inhaled allergen. This was accompanied by a significant increase in antigen-specific IgE and airway inflammation characterized by an influx of total leukocytes, macrophages, neutrophils, and lymphocytes into the airway lumen. The early airway response was not affected by $\mathrm{CD} 8^{+}$depletion.

The OX $-8^{+}$phenotype is expressed on rat cytotoxic $\mathrm{T}$ cells and noncytotoxic T suppressor cells (Ts) (24), as well as on a subset of natural killer cells (25), but not on peripheral T cells (CD4) that are labeled with W3/25 (24). We used the OX-8 monoclonal antibody to deplete $\mathrm{CD}^{+} \mathrm{T}$ cells in vivo because a number of reports suggested that this was an effective means to modulate the suppressive immune response. Mice injected with anti-Lyt-2 (CD8 ${ }^{+}$equivalent) demonstrated a prolonged sheep red blood cell IgM response compatible with a failure to develop a modulatory suppressor mechanism (30). In mice, other reports of in vivo depletion of $\mathrm{CD}^{+}$cells using monoclo-

Table I. Effect of OX-8 on Cellular Return of BAL in Unsensitized Rats*

\begin{tabular}{lccccc}
\hline & $\begin{array}{c}\text { Total } \\
\text { Leukocytes }\end{array}$ & Macrophages & Lymphocytes & Neutrophils & Eosinophils \\
\hline Saline & $3.88 \pm 0.02$ & $3.27 \pm 0.03$ & $0.51 \pm 0.01$ & $0.10 \pm 0.01$ & - \\
OX-8 $^{\ddagger}$ & $4.01 \pm 0.03$ & $3.56 \pm 0.03$ & $0.40 \pm 0.01$ & $0.05 \pm 0.02$ & -
\end{tabular}

* Values represent mean $\pm \mathrm{SE}\left(\times 10^{5}\right.$ cells $) .{ }^{\ddagger}$ After OX-8 $1 \mathrm{mg}$ i.v. $\times 3$ injections on days 8,10 , and 12 after sham sensitization. nal antibodies have demonstrated a suppressive role for $\mathrm{CD}^{+}$ cells $(31,32)$. In BB/Wor rats, a model of spontaneous diabetes mellitus, OX-8 depletion prevented lymphocytic destruction of pancreatic beta cells (33). $\mathrm{CD}^{+}$cells can also exert suppressive activity $(34,35)$. In our study, peripheral $\mathrm{CD}^{+}$cells were significantly depleted while $\mathrm{CD} 4^{+}$cells were not, suggesting that the former might be the final effector suppressive cells that play an important role in modulating the late airway reaction. The phenomenon of immune response suppression by $\mathrm{T}$ cells is well recognized. Downregulation of immune responses is believed to be determined by the joint activities of $\mathrm{CD}^{+}$inducer $\mathrm{T}$ cells and $\mathrm{CD} 8^{+} \mathrm{T}$ cells, including cytotoxic cells and Ts. A distinct Ts lineage likely exists (36), but there is no universal agreement on this point (37).

The sequence of events involved in immunosuppression is not entirely clear, but it has been postulated that Ts cells release suppressive factors that bind to antigen-presenting cells and other cells in secondary lymphoid tissue, and that these cells suppress effector cells such as $\mathrm{T}$ or B lymphocytes that arrive in that tissue $(38,39)$. Inhibition of Ts using monoclonal antibodies could interfere with such mechanisms. In vitro data using the mixed leukocyte reaction model suggest that Ts inhibit an early event during the activation of $\mathrm{CD}^{+}$cells (40).

In our study, there was an increase in antigen-specific IgE in OX-8-depleted animals. Presumably the increase in IgE reflects the removal of suppressor effects on activated $\mathrm{CD} 4^{+}$cells and a consequent promotion of B cell synthesis of IgE. The first dose of OX-8 monoclonal antibody was administered $8 \mathrm{~d}$ after antigen sensitization. It is possible that administration of antibodies before sensitization might result in even greater promotion of antigen specific IgE. In the rat, the late airway response is dependent on the presence of $\operatorname{IgE}(29)$ and correlates with the degree of $T$ cell activation (41). Thus, the late airway response may have been increased in the rat after peripheral $\mathrm{CD}^{+}$depletion through enhancement of IgE production or by disinhibition of $\mathrm{CD}^{+}$-activated cells. In humans, an increase in activated $\mathrm{CD}^{+}$cells has been observed infiltrating allergen-injected skin sites during the late phase cutaneous reaction (42), and in the blood and bronchial biopsies in both stable and acute asthma $(3,4,43,44)$.

We demonstrated a marked decrease in the percent of OX$8^{+}$cells in the blood and lungs in the rat after in vivo depletion. This finding could have reflected a reduction in the expression of OX-8 on the cell surface rather than suppressor cell depletion. However, depletion of $\mathrm{CD}^{+}$cells in rats and mice has been shown to inhibit suppressor cell function $(45,33)$. The findings of increased IgE, increased late airway bronchoconstriction, and increased cellular return from lung lavage strongly suggest that the function of suppressor cells was altered in the rats that received the monoclonal antibody. Furthermore, the administration of the OX-8 mAb itself did not affect the inflammatory cell population of the lung before allergen challenge, and therefore must have modified allergen responses through the modulation of mechanisms triggered by challenge.

Other studies have examined the relationship between lymphocyte subsets in the blood or the lung and the late airway response. Dual and late asthmatic reactions caused by toluene diisocyanate exposure in humans are associated with an increase in percent blood $\mathrm{CD}^{+}$and a decrease in the blood $\mathrm{CD}^{+} / \mathrm{CD}^{+}$ratio at 8 and $48 \mathrm{~h}$ after exposure (46). $\mathrm{CD}^{+}$cells do not change. Although toluene diisocyanate-related asthma 
shares some features of allergen-induced asthma, the immune reaction is not usually IgE mediated (47). Allergen-induced late airway responses are associated with a decrease in peripheral blood $\mathrm{CD}^{+}$cells, perhaps caused by active recruitment of these cells into the lungs $(48,28)$. Asthmatics who develop late phase responses after allergen challenge may have an inability to recruit $\mathrm{CD}^{+}$cells to the lung (49). Thus, a deficiency of $\mathrm{CD}^{+}$cells in the blood or the lung may contribute to an enhanced late airway response.

In conclusion, the late airway response to inhaled antigen was significantly increased using in vivo depletion of peripheral OX-8 binding $T$ cells in Sprague-Dawley rats. The underlying mechanism remains to be clarified, but does not likely involve mast cells, since the early airway response to antigen was not affected.

\section{Acknowledgments}

The authors would like to thank Mr. S. Seguin for his technical assistance and Ms. Barbara Kidd for her assistance in preparation of the manuscript.

Dr. R. Olivenstein was a recipient of a Canadian Lung Association Fellowship. Dr. P. M. Renzi is a Chercheur Boursier of the Fonds de Recherche en Santé du Québec. Dr. S. Laberge is a recipient of a Fonds de Recherche en Santé du Québec/Glaxo Fellowship. Dr. S. Waserman was a recipient of a Fonds de Recherche en Santé du Québec Fellowship. Dr. J. G. Martin is a recipient of a Scientist Award of the Medical Research Council of Canada.

\section{References}

1. Jeffery, P. K., A. J. Wardlaw, F. C. Nelson, J. V. Collins, and A. B. Kay. 1989. Bronchial biopsies in asthma: an ultrastructural quantitative study and correlation with hyperreactivity. Am. Rev. Respir. Dis. 140:1745-1753.

2. Gerblich, A. A., A. E. Campbell, and M. R. Schuyler. 1984. Changes in T lymphocyte subpopulation after antigenic bronchial provocation in asthmatics. N. Engl. J. Med. 310:1349-1352.

3. Corrigan, C. J., A. Hartnell, and A. B. Kay. 1988. T lymphocyte activation in acute severe asthma. Lancet. i:1129-1132.

4. Corrigan, C. J., and A. B. Kay. 1990. CD4 T lymphocyte activation in acute severe asthma. Relationship to disease severity and atopic status. Am. Rev. Respir. Dis. 141:970-977.

5. Leung, D. Y. M., and R. S. Geha. 1987. Regulation of the human IgE antibody response. Int. Rev. Immunol. 2:75-91.

6. Lopez, A. F., C. J. Sanderson, J. R. Gamble, H. D. Campbell, I. G. Young, and M. A. Vada. 1988. Recombirant human interleukin- 5 is a selective activator of human eosinophil function. 1988. J. Exp. Med. 167:219-224.

7. Yamaguchi, Y., Y. Hayashi, Y. Sugama, M. Yasusada, T. Kasahara, S. Kitamura, M. Torisu, S. Mita, A. Tominaga, K. Takatsu, and T. Suda. 1988. Highly purified murine interleukin-5 (IL-5) stimulates eosinophil function and prolongs in vitro survival. IL-5 is an eosinophil chemotactic factor. J. Exp. Med. 167:1737-1742.

8. Walsh, G. M., A. Hartnell, A. J. Wardlaw, K. Kurihara, C. J. Sanderson, and A. B. Kay. 1990. IL-5 enhances the in vitro adhesion of human eosinophils but not neutrophils, in a leukocyte integrin (CD11/18)-dependent manner. Immunology. 71:258-265.

9. Meininger, C. J., H. Yano, R. Rottapel, A. Bernstein, K. M. Zsebo, and B. R. Zetter. 1992. The c-kit receptor ligand functions as a mast cell chemoattractant. Blood. 79:958-963.

10. Haig, D. M., C. McMenamin, J. Redmond, D. Brown, I. G. Young, S. D. R. Cohen, and A. J. Hapel. 1988., Rat IL-3 stimulates the growth of rat mucosal mast cells in culture. Immunology. 65:205-211.

11. Canonica, G. W., M. C. Mingari, G. Melioli, M. Colombatti, and L. Moritta. 1979. Imbalances of $\mathrm{T}$ cell subpopulations in patients with atopic diseases and effect of specific immunotherapy. J. Immunol. 123:2669-2672.

12. Kus, J., K. S. Tse, D. Enarson, S. Grzybowski, and M. Chan-Yeung. 1984. Lymphocyte subpopulations in patients with allergic rhinitis. Allergy (Cph.). 39:509-514.

13. Faure, M. R., M. A. Gaucherand, J. Thivolet, J. M. Czernielewski, and J. F. Nicolas. 1982. Decreased levels of T cells and cells with suppressor T cell phenotype as defined by specific monoclonal antibodies in patients with atopic dermatitis. Clin. Exp. Dermatol. 7:513-518.

14. Engel, P., J. Huguet, J. Sanosa, P. Sierra, N. Cols, and P. A. Garcia-Calderon. 1984. T cell subsets in allergic respiratory disease using monoclonal antibodies. Ann. Allergy. 53:337-340.

15. Kus, J., K. S. Tse, S. Vedal, and M. Chan-Yeung. 1985. Lymphocyte subpopulations in patients with allergic and non-allergic asthma. Clin. Allergy. 15:523-529.

16. Walker, C. E. Bode, L. Boer, T. T. Hansel, K. Blaser, and J-C. Virchow Jr. 1992. Allergic and nonallergic asthmatics have distinct patterns of $T$ cells activation and cytokine production in peripheral blood and bronchoalveolar lavage. Am. Rev. Respir. Dis. 146:109-115.

17. Rivlin, J., O. Kuperman, S. Freier, and M. Godfrey. 1981. Suppressor T lymphocyte activity in wheezing children with and without treatment by hyposensitization. Clin. Allergy. 11:353-356.

18. Harper, T. B., H. R. Gaumer, W. Waring, R. B. Branon, and J. E. Salvaggio. 1980. A comparison of cell-mediated immunity and suppressor T-cell function in asthmatic and normal children. Clin. Allergy. 10:555-563.

19. Rola-Pleszczynski, M., and R. Blanchard. 1981. Suppressor cell function in respiratory allergy. Int. Arch. Allergy Appl. Immunol. 64:361-370.

20. Rocklin, R. E., A. L. Sheffer, D. K. Greineder and K. L. Melmon. 1980. Generation of antigen specific suppressor cells during allergy desensitization. $N$. Engl. J. Med. 302:1213-1219.

21. Hwang, K. C., S. M. Fikrig, H. M. Friedman, and S. Gupta. 1985. Deficient concanavalin A-induced suppressor-cell activity in patients with bronchial asthma, allergic rhinitis, and atopic dermatitis. Clin. Allergy. 15:67-72.

22. Ilfeld, D., Kivity, E. Feierman, M. Topilsky, and O. Kuperman. 1985. Effects of in vitro colchicine and oral theophylline on suppressor cell function of asthmatic patients. Clin. Exp. Immunol. 61:360-367.

23. Poznansky, M. C., A. C. H. Gordon, I. W. B. Grant, and A. H. Wyllie. 1985. A cellular abnormality in glucocorticoid resistant asthma. Clin. Exp. Immunol. 61:135-42.

24. Brideau, R. J., P. B. Carter, W. R. McMaster, D. W. Mason, and A. F. Williams. 1980. Two subsets of rat T lymphocytes defined with monoclonal antibodies. Eur. J. Immunol. 10:609-615.

25. Cantrell, D. A., R. A. Robins, C. G. Brooks, and R. W. Baldwin. 1981. Phenotype of rat natural killer cells defined by monoclonal antibodies marking rat lymphocyte subsets. Immunology. 45:97-103.

26. Sorkness, R., K. Johns, W. L. Castleman, and R. F. Lemanske Jr. 1990. Late pulmonary allergic responses in actively but not passively IgE-sensitized rats. J. Appl. Physiol. 69:1012-1021.

27. Renzi, P. M., R. Olivenstein, and J. G. Martin 1993. Inflammatory cell populations in the airways and parenchyma after antigen challenge of the rat. Am. Rev. Respir. Dis. 147:967-974.

28. Eidelman, D. H., S. Bellofiore, and J. G. Martin. 1988. Late airway responses to antigen challenge in sensitized inbred rats. Am. Rev. Respir. Dis. 137:1033-1037.

29. Waserman, S., R. Olivenstein, P. Renzi, L. J. Xu, and J. G. Martin. 1992. The relationship between late airway responses antigen specific immunoglobulin. J. Allergy Clin. Immunol. 90:661-669.

30. Philips, S. M., G. P. Linette, B. L. Doughty, J. E. Byram, and F. Von Lichtenberg. 1987. In vivo $\mathrm{T}$ cell depletion regulates resistance and mobility in murine schistosomiasis. J. Immunol. 139:919-926.

31. Leist, T. P., E. Ruedi, and R. M. Zinkernagel., 1988. Virus-triggered immune suppression in mice caused by virus-specific cytotoxic T cells. $J$. Exp. Med. 167:1749-1754.

32. Benaroch, P., E. Georgatsou, and G. Bordenave. 1988. Cellular induction of chronic allotype suppression of $\mathrm{IgG}_{2 \mathrm{a}}$ in $\mathrm{Igh}^{\mathrm{b} / \mathrm{b}}$ homozygous mice and its abrogation by in vivo treatment with anti-CD8 monoclonal antibody. J. Exp. Med. 168:891-904.

33. Like, A. A., G. A. Biron, E. J. Weringer, K. Byman, E. S. Roczynski, and D. L. Guberski. 1986. Prevention of diabetes in Biobreeding/Worcester rats with monoclonal antibodies that recognize T lymphocytes or natural killer cells. $J$. Exp. Med. 164:1145-1159.

34. Parish, N. M., I. M. Roitt, and A. Cooke. 1988. Phenotypic characteristics of cells involved in induced suppression to murine experimental autoimmune thyroiditis. Eur. J. Immunol. 18:1463-1467.

35. Titus, R. G., R. Ceredig, J.-C. Cerottini, and J. A. Louis. 1985. Therapeutic effect of anti-L3T4 monoclonal antibody GKJ.5 on cutaneous leishmaniasis in genetically susceptible BALB/c mice. J. Immunol. 135:2108-2114.

36. Damle, N. K., and E. G. Engleman. 1989. Antigen-specific suppressor T lymphocytes in man. Clin. Immunol. Immunopath. 53:S17-S24.

37. Mollar, G. 1988. Do suppressor T cells exist? Scand. J. Immunol. 27:247250. (Editorial.)

38. Dorf, M. E., and B. Benacerraf. 1984. Suppressor cells and immunoregulation. Ann. Rev. Immunol. 2:127-1.

39. Asherson, G. L. 1986. An overview of T-suppressor cell circuits. Ann. Rev. Immunol. 4:37-68. 
40. Damle, N. K., and E. G. Engelman. 1983. Immunoregulatory T cell circuits in man. Alloantigen-primed inducer $T$ cells activate alloantigen-specific suppressor T cells in the absence of the initial antigenic stimulus. J. Exp. Med. 158:159-173.

41. Waserman, S., L. J. Xu, R. Olivenstein, and J. G. Martin. 1992. The association between late allergic bronchoconstriction in the rat and allergen-stimulated lymphocyte proliferation in vitro. Am. Rev. Respir. Dis. A490. (Abstr.)

42. Frew, A. J., and A. B. Kay. 1988. The relationship between infiltrating $\mathrm{CD}^{+}$lymphocytes, activated eosinophils and the magnitude of the allergen-induced late phase cutaneous reaction in man. J. Immunol. 141:4158-4164.

43. Azzawi, M., B. Bradley, and P. K. Jeffery. 1990. Identification of activated $\mathrm{T}$ lymphocytes and eosinophils in bronchial biopsies in stable atopic asthmatics. Am. Rev. Respir. Dis. 142:1407-1413.

44. Hamid, Q., M. Azzawi, S. Ying, R. Moqbel, A. S. Wardlaw, C. J. Corrigan, B. Bradley, S. R. Durham, J. V. Collins, P. K. Jeffery, et al. 1991. Expression of mRNA for interleukin-5 in mucosal bronchial biopsies from asthma. J. Clin Invest. 87:1541-1546.

45. Sedgwick, J. D. 1988. Long term depletion of $\mathrm{CD} 8^{+} \mathrm{T}$ cells in vivo in the rat: no observed role for $\mathrm{CD}^{+}$(cytotoxic/suppressor) cells in the immunoregulation of experimental allergic encephalomyelitis. Eur. J. Immunol. 18:495-502.

46. Finotto, S., L. M. Fabbri, V. Rado, C. E. Mapp, and P. Maestrelli. 1991 Increase in numbers of CD8 positive lymphocytes and eosinophils in peripheral blood of subjects with late asthmatic reactions induced by toluene diisocyanate. Br. J. Ind. Med. 48:116-121.

47. Cartier, A., L. Grammer, J. L. Malo, F. Lagier, H. Ghezzo, K. Harris, and R. Patterson. 1989. Specific serum antibodies against isocyanates: association with occupation. J. Allergy Clin. Immunol. 84(4):507-514.

48. Metzger, W. J., D. Zavala, H. B. Richerson, P. Moseley, P. Iwamota, M. Monick, K. Sjoerdsma, and G. W. Hunninghake. 1987. Local allergen challenge and bronchoalveolar lavage of allergic asthmatic lungs. Description of the model and local airway inflammation. Am. Rev. Respir. Dis. 135:433-440.

49. Gonzalez, M. C., P. Diaz, F. R. Galleguillos, P. Ancic, O. Cromwell, and A. B. Kay. 1987. Allergen-induced recruitment of bronchoalveolar helper (OKT4) and suppressor (OKT8) T-cells in asthma. Relative increases in OKT8 cells in single early responders compared with those in late-phase responders. $\mathrm{Am}$. Rev. Respir. Dis. 136:600-604. 